\title{
Morphological variation and a remarkable new sexual dimorphism in the Pseudocyclops xiphophorus population of Lake Faro in northeastern Sicily
}

\author{
CINZIA BRUGNANO ${ }^{1}$, GEOFFREY A. BOXSHALL ${ }^{2}$, GIUSEPPE COSTANZO ${ }^{1}$ \\ and GIACOMO ZAGAMI ${ }^{1}$ \\ ${ }^{1}$ Department of Animal Biology and Marine Ecology, Messina University, Salita Sperone 31, 98166 S. Agata, Messina, \\ Italy. E-mail: cinzia.brugnano@unime.it \\ ${ }^{2}$ Department of Zoology, The Natural History Museum, Cromwell Road, London SW7 5BD, U.K.
}

SUMMARY: The population of $P$. xiphophorus in Lake Faro exhibits variation in the form of caudal seta V. In some specimens of both sexes, this seta is spatulate but in others it is slender and unmodified. Occasional specimens are asymmetrical. In addition to this variation in caudal seta form, the Lake Faro population displays variation in male body length and in the extent of the sexually dimorphic specialisation of the right swimming leg 2 . The scale of these differences between the morphotypes might suggest their taxonomic treatment as distinct species. The modification of the distal two segments of the exopod of right leg 2 in the male is a unique sexual dimorphism. We infer, from the presence of this hook on the right exopod in adult males only, that it is involved in mating behaviour. Laboratory-based breeding experiments between females and males showing different combinations of these characters were also performed. Experiments comparing egg production rates in females that have mated with modified or unmodified males revealed no significant differences. It appears therefore that gene flow is not interrupted between the morphotypes and that reproductive segregation does not occur. Observations of male leg 5 morphology and musculature revealed no significant differences between the two P. xiphophorus morphotypes.

Keywords: Pseudocyclops xiphophorus population, Lake Faro, morphotypes, sexual dimorphism, morphological observation and interbreeding experiments.

RESUMEN: VARIACIÓN MORFOLÓGICA Y UN NUEVO Y REMARCABLE TIPO DE DIMORFISMO SEXUAL EN LA POBLACIÓN DE

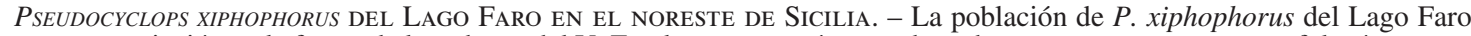
muestra variación en la forma de la seda caudal V. En algunos especímenes de ambos sexos presenta una morfología espatulada, pero en otros es esbelta y sin modificaciones. Ocasionalmente, es asimétrica en un mismo individuo. La población del Lago Faro muestra también variabilidad en la longitud corporal del macho y en el grado de dimorfismo sexual de la segunda pata natatoria derecha. La escala de estas diferencias entre morfotipos podría sugerir un tratamiento específico diferente para ellos. La modificación en el macho de los dos segmentos distales del exópodo de la segunda pata natatoria derecha es un carácter desconocido en otras especies del género. La presencia de un gancho en el exópodo derecho de los machos sugiere que esta modificación está relacionada con el comportamiento de apareamiento. Se han realizado cruzamientos en laboratorio entre hembras y machos que mostraban diferentes combinaciones de estos caracteres. La comparación de las tasas de producción de huevos en hembras que se han cruzado con machos con o sin modificaciones no muestra diferencias significativas. Parece por tanto que el flujo génico entre morfotipos no está interrumpido y que no tiene lugar segregación reproductiva. La observación de la morfología y del patrón muscular de la pata quinta del macho no ha revelado tampoco diferencias significativas entre los dos morfotipos de P. xiphophorus.

Palabras clave: población de Pseudocyclops xiphophorus, Lago Faro, morfotipos, dimorfismo sexual, observación morfológica y experimentos de entrecruzamiento. 


\section{INTRODUCTION}

Hyperbenthic calanoid copepods are important by virtue of their unique ecology, biogeography and phylogenetic history. Despite the relatively small number of known species and their typically low abundance, this ecological grouping plays a significant role in increasing the functional diversity of marine and brackish coastal ecosystems. From a biogeographic point of view, the hyperbenthic $\mathrm{Ca}-$ lanoida recorded in the Mediterranean contribute to our knowledge of the origin of the Mediterranean fauna and of the relationships of the Mediterranean basin with the Atlantic and Indo-Pacific Oceans over geological timescales. From the phylogenetic point of view, the hyperbenthic Calanoida include some of the most basal families of the order, such as the Pseudocyclopidae and Ridgewayiidae, as well as representatives of little known families like the Arietellidae, Pseudocyclopiidae, Stephidae and Epacteriscidae. The discovery of new hyperbenthic species and their developmental stages provides an important contribution to knowledge of the evolutionary history of the copepods.

Pseudocyclops xiphophorus Wells, 1967, originally found along the coast of Inhaca Island (Mozambique) in the Indian Ocean (Wells, 1967), was reported in Lake Faro-the first record from the Mediterranean Sea-and redescribed by Zagami et al. (2005). In Lake Faro this species was found in fouling attached to submerged ropes and mooring posts. Lake Faro (surface area 263,600 $\mathrm{m}^{2}$, max depth $28 \mathrm{~m}$ ) is a coastal lagoon located at the northeastern tip of Sicily at $38^{\circ} 16^{\prime} \mathrm{N}, 15^{\circ} 38^{\prime} \mathrm{E}$ (Fig. 1). It has the typical features of a meromictic basin, i.e. an oxic epilimnion and an anoxic hypolimnion, characterised by large fluctuations in physico-chemical parameters, especially temperature $\left(10-28^{\circ} \mathrm{C}\right)$, salinity (34-37 PSU) and dissolved oxygen (ranging from absent near the bottom in the central area to $8.3 \mathrm{mg} / \mathrm{l}$ in surface along the shore). These layers are separated by a metalimnion, within which strong blooms of anoxygenic phototrophic bacteria cause the periodic development of a red water layer (Genovese, 1963; Truper and Genovese, 1968).

Ohtsuka et al. (1999) included $P$. xiphophorus in the magnus-group of species, the members of which share an important synapomorphy: seta $\mathrm{V}$ on the caudal ramus is spatulate in the female (in P. magnus Esterly, 1911, P. xiphophorus and P. bilobatus Dawson, 1977). However, we have discovered that

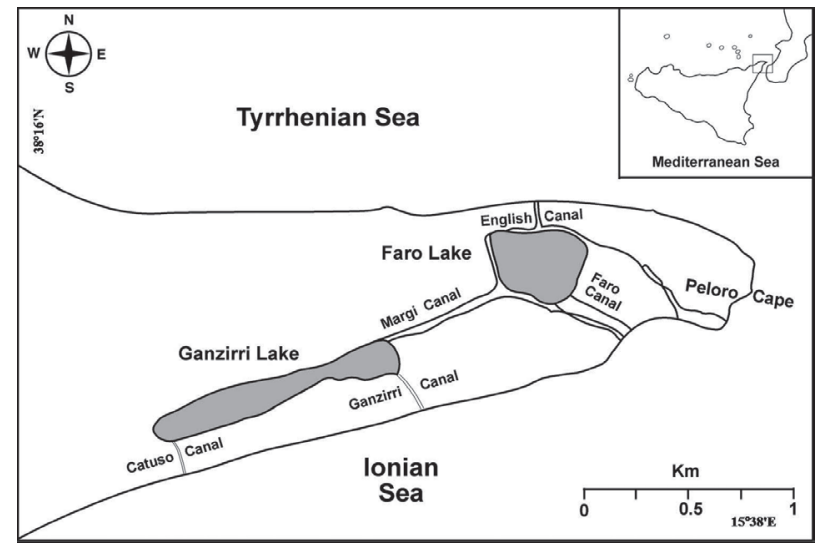

FIG. 1. - Location of Lake Faro at the northeastern tip of Sicily.

the population of $P$. xiphophorus in Lake Faro exhibits variation in the form of caudal seta V. In some specimens of both sexes, this seta is spatulate but in others it is slender and unmodified. Occasional specimens are asymmetrical. In addition to this variation in caudal seta form, the Lake Faro population displays variation in male body length, and in the extent of the sexually dimorphic specialisation of the right swimming leg 2 .

The scale of these differences between the morphotypes might suggest their taxonomic treatment as distinct species. This paper examines the variability in caudal setae and characterises in detail the remarkable sexual dimorphism in leg 2. It also reports on results of laboratory-based breeding experiments between females and males showing different combinations of these characters. The male fifth leg, which usually provides diagnostic characters indicative of species level differences in this genus, is also re-examined in detail and its intrinsic musculature is described for the first time.

\section{MATERIAL AND METHODS}

Fouling samples were collected by hand. Submerged ropes to which fouling was attached were placed directly in plastic containers together with environmental water and the ropes were then cut. The fouling samples were taken directly to the laboratory. Live $P$. xiphophorus specimens were sorted from the fouling washing water under a stereo microscope and transferred to an aquarium containing $100 \mathrm{ml}$ of filtered sea water. In the aquarium $P$. xiphophorus was reared on a mixed diet of three phytoplankton species: Tetraselmis suecica, Pavlova lutheri and 
Isochrysis galbana. Egg production was monitored daily for each pair of males and females placed individually into $50 \mathrm{ml}$ crystallising dishes containing filtered sea water enriched with the same diet given in excess concentrations. After the death of the female, each couple was preserved in $4 \%$ formaldehyde in seawater. This experimental method was used in a preliminary study of egg production rates and the life cycle of $P$. xiphophorus over a range of different temperatures (Brugnano et al., 2006).

In order to test the extent of interbreeding between the morphotypes, two experimental crosses were carried out: one between females and males with large body size and modified leg 2 , and one between females and males with normal body size and unmodified leg 2. Egg production and the viability of produced eggs were measured. The significance of the differences between crosses was tested by means of the Student $t$ test, using data from pairs with modified and unmodified males maintained at 16 and $20^{\circ} \mathrm{C}$. Egg production measurements were curtailed after 80 and 45 days, respectively. About twenty breeding pairs from the laboratory experiments were preserved in a $4 \%$ buffered formaldehyde and sea water solution, and body lengths were measured under a light microscope. Some were dissected in lactophenol and observed as temporary preparations using differential interference contrast microscopy (Leitz Ortholux microscope). Terminology for the description of the intrinsic musculature of the legs follows Boxshall (1982). For comparison, the type material of $P$. xiphophorus and some material from Hong Kong stored in the collections of The Natural History Museum, London, was re-examined.

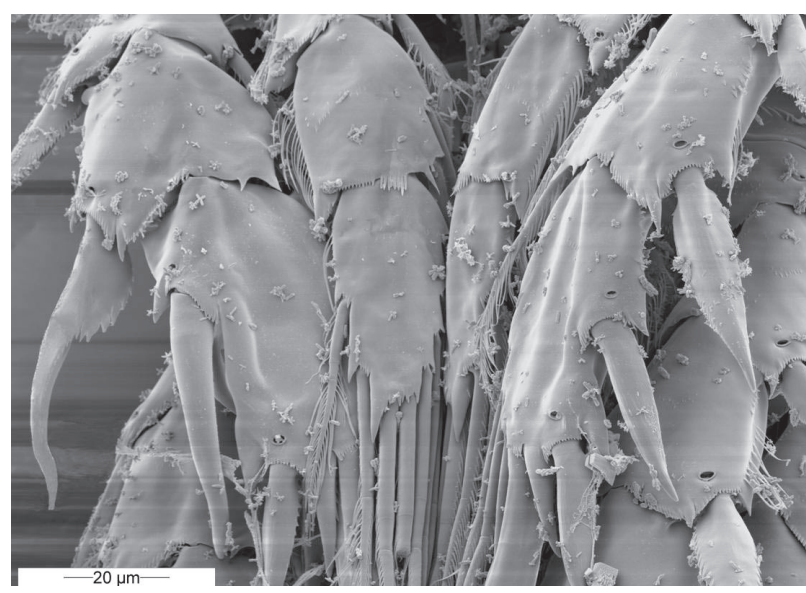

FIG. 2. - Scanning electron micrograph of second pair of swimming legs of male $P$. xiphophorus from Lake Faro, showing asymmetry in form of spine on outer margin of second exopodal segment. Anterior view, showing spine modified on right side but unmodified on left.
Five modified and four unmodified males were processed for scanning electron microscopy (SEM). Material for SEM was washed in distilled water, dehydrated through a graded acetone series, critical-point dried using liquid carbon dioxide as the exchange medium, mounted on aluminium stubs and sputter coated with palladium. Coated specimens were examined using a Phillips XL30 field emission scanning electron microscope operating at $5 \mathrm{KV}$. Morphological terminology follows Huys and Boxshall (1991).

\section{RESULTS}

\section{Morphology}

Second swimming leg: The leg 2 of adult male $P$. xiphophorus shows a unique and asymmetrical modification of the distal segments of the exopod (Fig. 2). The outer spine on the second exopodal segment of the right leg differs in shape from the corresponding spine on the left leg, where it is a normal bipinnate spine. The spine on the right leg is larger and has a well developed row of denticles on the inner margin (Fig. 3A). The proximal spine on the third exopodal segment of the right leg is typically larger than its counterpart of the left leg and is strongly curved. This outer spine is also positioned more proximally than the corresponding spine on the left and on the anterior surface of the segment rather than on its margin. In addition, the lateral margins of the two exopodal segments are more heavily sclerotised on the right side than on the left.

This unique asymmetry in male leg 2 was present in a $P$. xiphophorus male from Hong Kong (BMNH Reg. N. 1989.136) (Fig. 3B), but absent in the male paratype (BMNH Reg. N. 1967.8.4.2) (Fig. 3C) from Mozambique, as well as in males from Lake Faro. However, in the males of the Lake Faro population the extent of this characteristic modification was variable. In some specimens the exopod of the right leg was unmodified (Fig. 3D) so that it was essentially identical to the left exopod (cf. Fig. 2). In others the modification of the right leg was weakly expressed (Fig. 4) with only slight proximal swelling of the outer spine of the second exopodal segment, and only slight thickening and change to a curved format in the proximal spine on the third segment. In a sample of 28 males, 24 (86\%) had a modified right leg 2 , and $4(14 \%)$ were unmodified or only weakly 

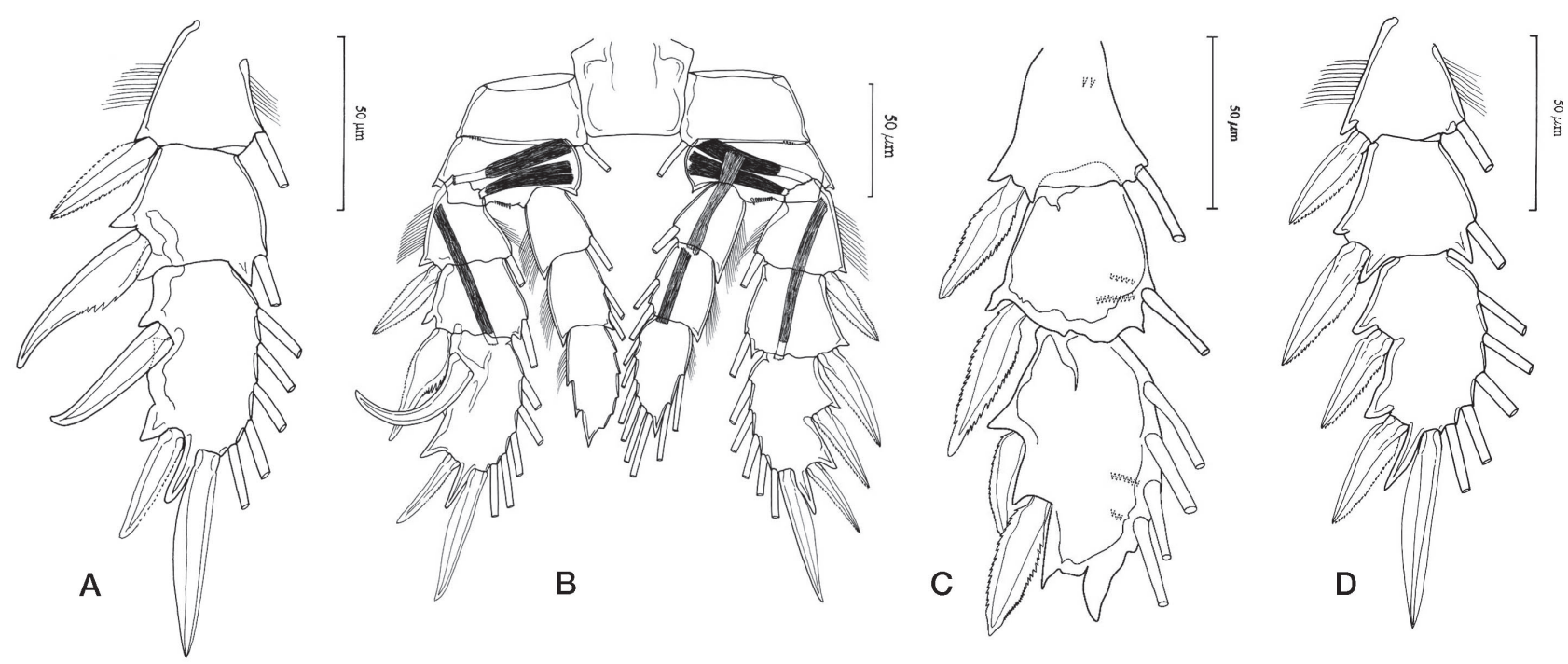

FIG. 3. - A, right exopod of leg 2 of male P. xiphophorus from Lake Faro showing modifications to second and third exopodal segments and their outer spines; anterior view. B, second leg pair of male P. xiphophorus from Hong Kong (BMNH Reg. No. 1989.136) with highly modified right exopod; anterior view, showing intrinsic musculature (endopodal muscles and endopodal setae omitted from right side). C, right exopod of leg 2 of paratype male of P. xiphophorus (BMNH Reg. No. 1967.8.4.2); anterior view showing unmodified outer margin spines and the presence of spinule rows on posterior surface (dotted) which indicates that isolated ramus is from right side. D, right exopod of leg 2 of male $P$. xiphophorus from Lake Faro - unmodified morphotype; anterior view.

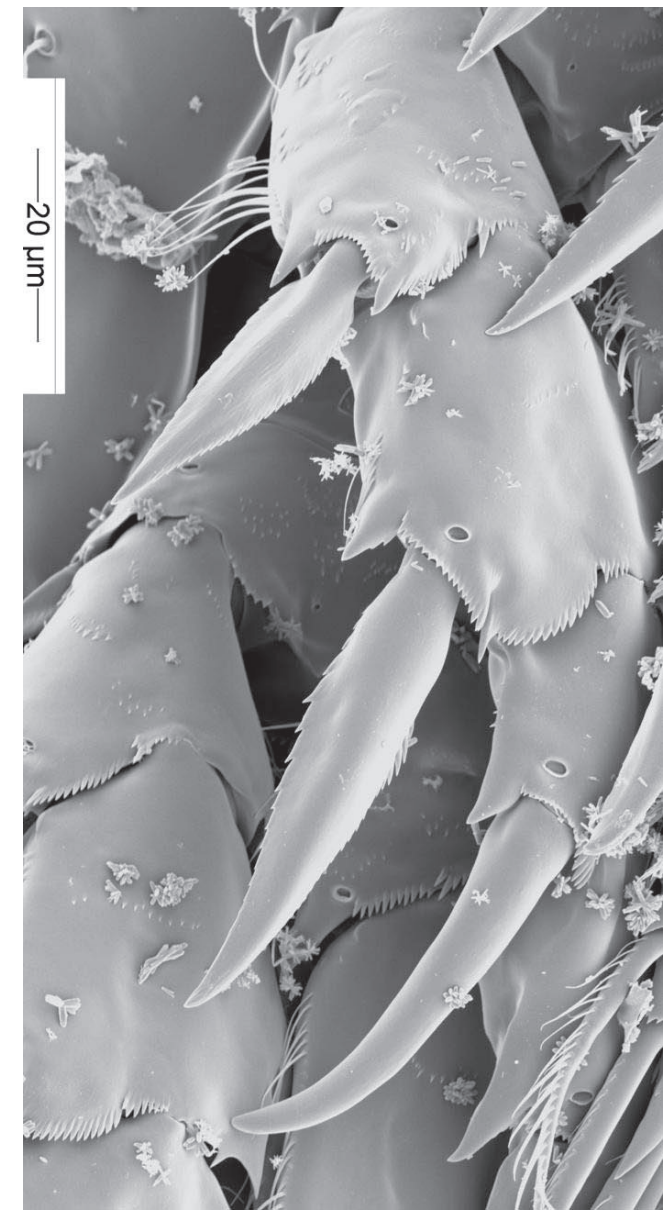

FIG. 4. - Scanning electron micrograph of right exopod of leg 2 of male P. xiphophorus from Lake Faro, antero-lateral view showing weak modifications of proximal spine on outer margin of third exopodal segments. modified. These are referred to below as modified and unmodified male morphotypes, respectively.

Size. The body length of male $P$. xiphophorus with a modified leg 2 ranged from 0.634 to 0.652 $\mathrm{mm}$, with a mean of $0.639 \mathrm{~mm}$, compared with the morphotype retaining an unmodified leg 2 which ranged from 0.580 to $0.616 \mathrm{~mm}$, with a mean of 0.598. This difference is significant $(\mathrm{T}=4.09$, d.f. $=4, \mathrm{P}<0.05)$.

Caudal setation. In both morphotypes and in both sexes, the caudal ramus bears six setae, with seta II spiniform and flattened with a terminal flagellum; seta $\mathrm{V}$ is the longest and is typically spatulate or sword-shaped in form. It was confirmed as spatulate in the type specimens (BMNH Reg. N. 1967.8.4.1-3; as described by Wells, 1967) as well as in the material identified by Malt from Hong Kong (BMNH Reg. N. 1989.136). Caudal seta V showed variation in shape in both sexes in the Lake Faro material. In this population some males and some females possessed a slender, unmodified caudal seta $\mathrm{V}$, while others exhibited the typical spatulate form as redescribed by Zagami et al. (2005). The form of caudal seta $\mathrm{V}$ not only varies between individuals in the Lake Faro population but, rarely, both setal types can be found on a single specimen (Fig. 5): with one caudal ramus carrying a spatulate seta $\mathrm{V}$ and the other one carrying a slender seta V. In a sample of 28 males, 


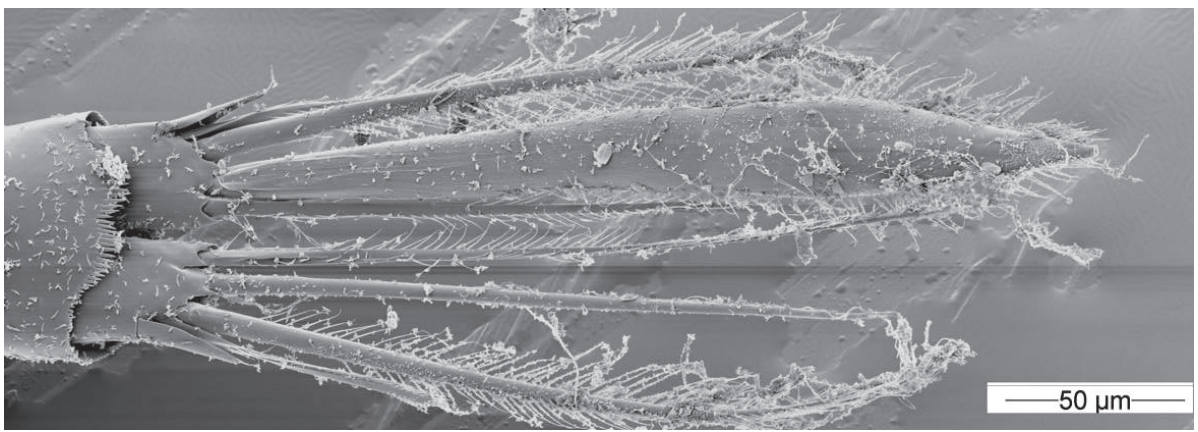

FIG. 5. - Scanning electron micrograph of anal somite and caudal rami, ventral view showing modified spatulate caudal seta $\mathrm{V}$ on left side and slender unmodified seta on right side.

TABLE 1. - Swimming leg formula in the two morphotypes.

Coxa Basis Exopodal segment Endopodal segment

\begin{tabular}{lllcl}
\hline Leg 1 & $0-1$ & $0-0$ & I-1; I-1; II, I, 4 & $0-1 ; 0-2 ; 1,2,3$ \\
Leg 2 & $0-1$ & $0-0$ & I-1; I-1; II, I, 5 & $0-1 ; 0-2 ; 2,2,4$ \\
Leg 3 & $0-1$ & $0-0$ & I-1; I-1; III, I, 5 & $0-1 ; 0-2 ; 2,2,4$ \\
Leg 4 & $0-1$ & $1-0$ & I-1;I-1; I-1; III, I, 5 & $0-1 ; 0-2 ; 2,2,3$ \\
\hline
\end{tabular}

$23(82 \%)$ had spatulate caudal seta V, 4 (14\%) had a slender seta $\mathrm{V}$ and only 1 (4\%) was asymmetrical, with one side modified.

Other appendages. The antennules and mouthparts of both morphotypes are similar and as described by Zagami et al. (2005). The swimming leg formula is identical in the two morphotypes (Table 1).
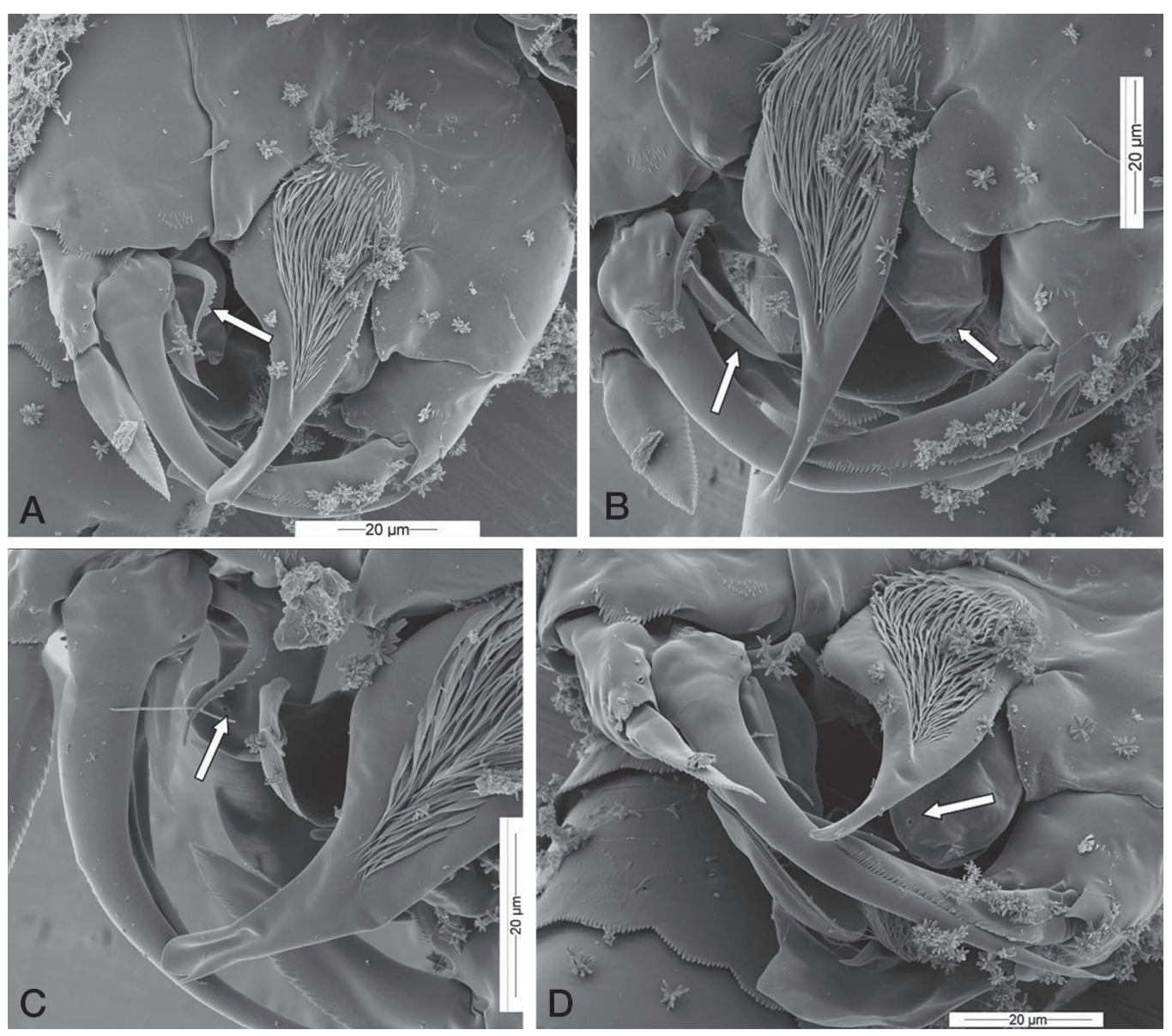

FIG. 6. - Scanning electron micrographs of fifth leg pair of male P. xiphophorus from Lake Faro. A, anterior view showing suture separating coxa and basis on right side and tapering process arising from undivided protopod on left side; $\mathrm{B}$, antero-lateral view showing previously unrecognised lobate endopod (arrowed) on left side; $\mathrm{C}$, antero-lateral view showing ornamentation on left protopodal process and margins of lamellate processes representing distal exopodal segments on left side; D, antero-ventral view showing integumental pore on left endopodal lobe and distal lamellate process of left exopod. 


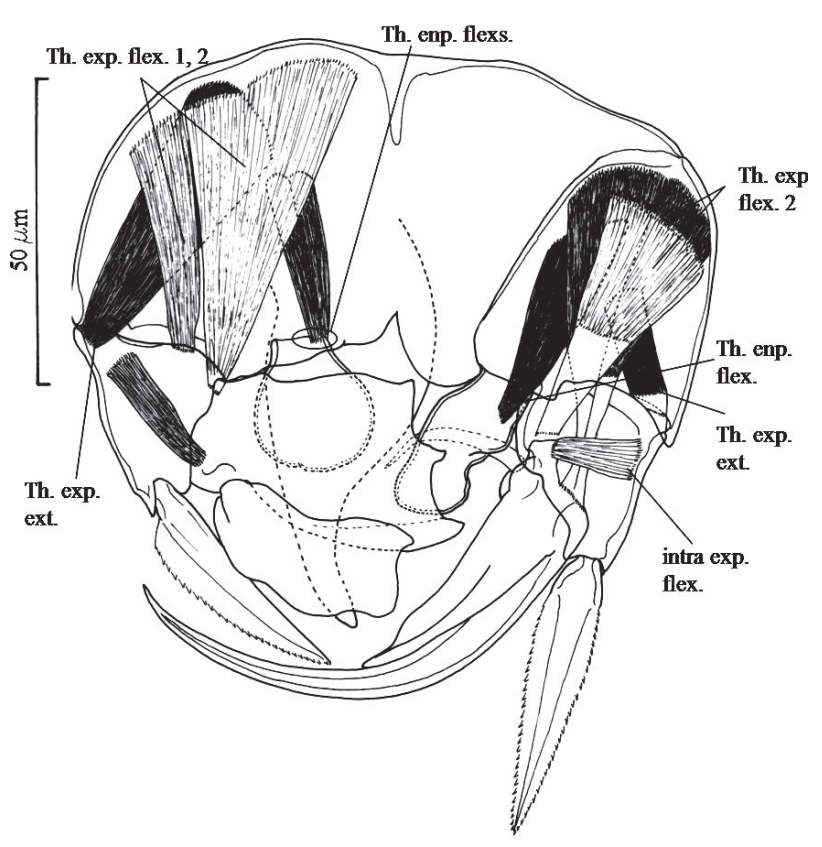

FIG. 7. - Fifth leg pair of male P. xiphophorus from Lake Faro. Posterior view, showing intrinsic musculature to rami on both sides. (Plumose setae on protopodal segments omitted for clarity.) Abbreviations: enp, endopodal; exp, exopodal; ext, extensor; flex, flexor, flexs, flexors, intra, intra, Th, thoracopods.

The fifth leg of male $P$. xiphophorus is complex (Figs 6,7) and its structure has never been fully elucidated. The coxa and basis are not separate on the left leg but are separate on the right (Fig. 6A). On the right leg, the basis carries a small plumose seta laterally on the posterior surface (omitted from Fig. 7 for clarity). The right exopod comprises a proximal segment and two distal spinous processes which represent the distal exopodal segments. The first exopodal segment bears a bipinnate outer spine and the second one bears a strongly curved inner seta (arrowed in Fig. 6A) ornamented with a row of denticles on one side. The longer exopodal process is strongly curved and claw-like, carrying proximally a spinous element with strong flanges on both sides (arrowed in Fig. 6B). The shorter exopodal process is apparently unarmed. The unsegmented endopod has an irregular outer margin that forms two small swellings and is unarmed. It is ornamented with a small pore (Fig. 6C).

The left leg carries an elongate, flattened process on the anterior surface of its undivided protopod. This lamellate process is broad proximally but tapers distally towards a slightly curved and bifid tip (Fig. $9 \mathrm{c})$. It is ornamented with long surface setules on the wider proximal part. A plumose seta is present on the posterior surface of the undivided protopod (omitted from Fig. 7 for clarity). The exopod is in- distinctly 3-segmented. The first exopodal segment bears one bipinnate spine at its outer distal angle. The distal part of the exopod is composed of two laminar plates that probably represent the second and third exopodal segments. No vestiges of setal elements were observed on these segments. The endopod is an unsegmented lobe which is unarmed, but is ornamented with one pore distally (Fig. 6D).

The intrinsic musculature of the male fifth legs is similar on both sides (Fig. 7). On the right side the origins of the intrinsic muscles to the rami are located distal to the coxa-basis articulation. Three robust muscles originate in the basis and insert within the exopod. The short exopodal extensor muscle (Th. exp. ext.) originates on mid-anterior wall of the basis and inserts laterally on the rim of the first exopodal segment. This muscle swings the exopod laterally and is opposed by the posterior exopodal flexor (Th. exp. flex. 2), which originates on the posterior wall of the basis and inserts via a long tendinous section, medially just inside the proximal rim of the segment. The third exopodal muscle (Th. exp. flex. 1) originates proximally within the basis and inserts laterally, via a long tendinous section, on the base of the claw formed by the distal exopodal segments. This muscle abducts the claw and is opposed by a short intraexopodal adductor that originates on the lateral wall of the first exopodal segment and inserts medially at the base of the claw. There is a single endopodal muscle originating somewhat medially on the anterior wall of the basis and inserting laterally just inside the base of the elongate, unsegmented endopod.

On the left leg the basic pattern is the same but the main muscles are larger and their origins spread more widely through the undivided protopodal segment (Fig. 7). The exopodal extensor muscle originates proximally on the anterior wall of the protopod and inserts laterally on the rim of the first exopodal segment. It is opposed by both exopodal flexors (Th. exp. flex. 1 and 2), which originate proximally on the posterior wall of the protopod and insert directly onto the medial section of the proximal rim of the segment. Neither extends into the segment and neither inserts via a tendinous section. The short intraexopodal muscle originates laterally on the first exopodal segment and inserts medially inside the first laminar plate (probably representing the second exopodal segment). The endopodal muscle appears to comprise a double strand originating on the anterior wall of the protopod and inserting just inside the base of the unsegmented, lobate endopod. 
TABLE 2. - Total egg production rates and mean daily egg production rates in the two morphotypes.

\begin{tabular}{|c|c|c|}
\hline $\begin{array}{l}\text { Male morphotype used in cross } \\
\text { breeding experiment }\end{array}$ & $\begin{array}{l}\text { Total egg production } \\
\text { Mean: (N) }\end{array}$ & $\begin{array}{l}\text { Daily egg production } \\
\text { Mean: }(\mathrm{N})\end{array}$ \\
\hline \multicolumn{3}{|l|}{ o normal size, P2 not modified } \\
\hline $16^{\circ} \mathrm{C}$ (duration 80 days) & 184 eggs female $^{-1}:(2)$ & 2.3 eggs female ${ }^{-1}$ day $^{-1:}(2)$ \\
\hline $20^{\circ} \mathrm{C}$ (duration 45 days) & 117.5 eggs female ${ }^{-1}:(2)$ & 2.6 eggs female ${ }^{-1}$ day $^{-1}:(2)$ \\
\hline \multicolumn{3}{|l|}{ targe, P2 modified } \\
\hline $16^{\circ} \mathrm{C}$ (duration 80 days) & 179 eggs female ${ }^{-1}:(2)$ & 2.2 eggs female ${ }^{-1}$ day $^{-1:}(2)$ \\
\hline $20^{\circ} \mathrm{C}$ (duration 45 days) & 145.5 eggs female ${ }^{-1}:(2)$ & 3.2 eggs female ${ }^{-1}$ day $^{-1}$ ( $(2)$ \\
\hline
\end{tabular}

Light and scanning electron microscopy revealed no significant differences between the two male morphotypes in the form of leg 5.

\section{Interbreeding experiments}

Both morphotypes reproduced successfully at the two temperatures. Total egg production rates and mean daily egg production rates were calculated (Table 2).

In relation to the different temperatures, total egg production differed slightly between modified and unmodified type, but the difference was not significant at either $16^{\circ} \mathrm{C}$ (Student $t$ test, $\mathrm{T}=0.27, P>0.05$; d. f.: 2 ) and at $20^{\circ} \mathrm{C}$ (Student $t$ test, $\mathrm{T}=3.84, P>0.05$; d. f.: 2). Mean daily egg production of pairs with unmodified and modified males was 2.3 and 2.2 and 2.6 and 3.2 eggs female ${ }^{-1}$ day $^{-1}$ respectively at 16 and $20^{\circ} \mathrm{C}$. The offspring of all crosses were able to produce fertile eggs.

\section{DISCUSSION}

The modification of the distal two segments of the exopod of right leg 2 in the male is a unique sexual dimorphism. It is expressed only in the adult, never in the preceding male copepodid stages. We infer, from the presence of this hook on the right exopod in adult males only, that it is involved in some way in mating behaviour, possibly in assisting to secure the attachment of the male to the female during spermatophore transfer. However, we have no direct observations on the role of this exopodal hook. Interestingly, a similar modification was described by Vervoort (1964) in the male of Pseudocyclops pacificus Vervoort, 1964. However, in P. pacificus, the modification of the exopod of right leg 2 differs in detail. It is restricted to the third exopodal segment and it is the middle of the three marginal spines that is developed into a strongly curved hook (Vervoort,
1964: Fig. 4c). In contrast, in P. xiphophorus the second and third segments are both modified and it is the proximal spine on the third that is hook-like, and it originates on the anterior surface of the segment rather than its margin. This strong asymmetry in modified males is a kind of sexual dimorphism that is unique in the Calanoida and has never been described before (cf. Ohtsuka and Huys, 2001). Sexual dimorphic asymmetry of swimming legs 1 to 4 is extremely rare in calanoids in general, although an asymmetrical modification of the basis of leg 4 has recently been found in a new species of Centropages (Boxshall and Jaume, pers. com.) from Vanuatu.

The $P$. xiphophorus population in Lake Faro exhibits remarkable variability in the form of male leg 2. The exopodal hook may be well developed, weakly developed or unmodified. The same modification was expressed in a $P$. xiphophorus specimen from Hong Kong (Fig. 4), but was not expressed in the male paratype of Wells (1967). Zagami et al. (2005) did not refer to it in their redescription based on Lake Faro material.

Experiments comparing egg production rates in females that have mated with modified or unmodified males revealed no significant differences (Table 2 ). It appears therefore that gene flow is not interrupted between the morphotypes and that reproductive segregation does not occur. Many studies have reported intraspecific morphological variation in copepods in relation to geographic distribution or to environmental plasticity (Elgmork and Halvorsen, 1997). In addition there can be problems associated with morphological stasis due to maintenance of a standard morphology over periods of time in populations that are reproductively isolated (Lee and Frost, 2002). Further investigation will need to undertake a molecular analysis in order to estimate genetic differences between $P$. xiphophorus morphotypes.

Despite the complexity of male leg 5 , our observations of its morphology and musculature revealed no significant differences between the two P. xipho- 
phorus morphotypes. A detailed study of the intrinsic musculature and a comparison with male fifth legs in P. umbraticus Giesbrecht, 1893 and P. obtusatus Brady and Robertson, 1873 allowed us to recognise the homology of the various components of the leg. All three species carry a process on the anterior surface of the protopod but it is thinner and more distally located in P. umbraticus and P. obtusatus than in P. xiphophorus. The exopods on both right and left legs are generally similar in all three species. All exopodal and endopodal segments exhibit pores on their surface that provide additional evidence aiding identification of these structures. The endopods are more variable. In $P$. umbraticus the left endopod is ornamented with four terminal setae and is clearly different from the other two species. The reduced, lobate endopod on the right leg of $P$. xiphophorus was overlooked or misinterpreted as a swelling on the basis in previous studies. Its interpretation here as a modified endopod is based on the presence of the endopod muscle and on the presence of an integumental pore on its surface, as present on the left endopod.

Pseudocyclops xiphophorus takes its name from the spatulate caudal seta V (Wells, 1967). The same caudal seta is spatulate in P. magnus Esterly, 1911 and in P. bilobatus Dawson, 1977 (Esterly, 1911; Dawson, 1977). Modifications of caudal setae in the same genus were also reported by Sewell (1932), who described a form bearing a modified caudal seta V as Pseudocyclops obtusatus var. latisetosus. This is now treated as a valid species, $P$. latisetosus Sewell, 1932. Sewell (1932) distinguished it from the typical form in which the two longest caudal setae were normal and slender in form but not appreciably stouter than the other setae. In P. latisetosus these two setae are considerably thickened and flattened proximally, but about half way along their length, the width suddenly decreases. The lateral margins of the proximal parts of the setae are ornamented with numerous small pinnules, whereas the distal parts are plumose. Minor variation in caudal seta shape was also reported for some Pseudocyclops species from the Bahamas by Fosshagen (1968).

Modified oar-shaped or club-shaped setae have been reported on the appendages and caudal rami of other planktonic copepod genera. Caudal seta V is modified into a broad flattened element in some species of Paracartia Scott, 1894, such as P. grani Sars, 1904 and P. latisetosa (Giesbrecht, 1892) (Sars, 1904; Labbé, 1929; Giesbrecht, 1892). It is remarkable that this same seta has become modified independently in representatives of genera from two unrelated families within the Calanoida. These two genera share in common a preference for brackish habitats, such as estuaries and lagoons. Fosshagen (1970) showed the same caudal seta V to be modified in the ridgewayiid Placocalanus nannus Fosshagen, 1970 but this bottom-living calanoid lives at a depth of 12 to $45 \mathrm{~m}$ on a sandy bottom off Conception Island in the Bahamas and is not associated with brackish conditions. It would be interesting to compare the genetic basis for the modification in all three genera.

In the genus Oncaea Philippi 1843, Boxshall and Böttger (1987) found flattened, oar-shaped setae on leg 4 and on all swimming legs, respectively, of $O$. atlantica Shmeleva, 1967 and O. platysetosa Boxshall and Böttger, 1987. They also showed that the outer seta on the basis of both the first and the second swimming legs was oar-shaped in female $O$. vodjianitski Shmeleva and Delalo, 1965 from the Red Sea, although such modified setae were not illustrated by Shmeleva and Delalo (1965) in their original description of the species, nor were they mentioned by Krišnić and Malt (1985) in their redescription based on Mediterranean material. It is possible that this indicates intraspecific variation in setal form in $O$. vodjianitski. Similar variation was found by Nishida (1985) in the planktonic cyclopoid Oithona setigera Dana, 1852, with some specimens possessing a modified club-shaped seta on the swimming legs and others carried a typical tapering seta.

\section{ACKNOWLEDGEMENTS}

One of us (CB) would like to thank the National Centre of Research (CNR) in Italy for supporting her study visit to The Natural History Museum of London. This paper is a direct product of the Short Mobility Programme of the CNR. Our colleague, Dr Damià Jaume (CSIC-IMEDEA), kindly translated the summary into Spanish. The authors are grateful to the reviewers for their suggested improvements to our manuscript.

\section{REFERENCES}

Boxshall, G.A. - 1982. On the anatomy of the misophrioid copepods, with special reference to Benthomisophria palliata Sars. Phil. Trans. Roy. Soc. Lond. Ser. B., 297: 125-181. 
Boxshall, G.A. and R. Böttger. - 1987. Two new species of Oncaea (Copepoda: Poecilostomatoida) from the Red Sea and a redescription of O. atlantica Shmeleva. J. Plankton Res., 9(Suppl. 3): $553-564$

Brugnano, C., G. Zagami and A. Granata. - 2006. Preliminary data on egg production rates of Pseudocyclops xiphophorus Wells, 1967 from the brackish lake Faro (North-eastern Sicily). Chem. Ecol., 22(Suppl. 1): 191-195.

Dawson, J.K. - 1977. A new species of Pseudocyclops (Copepoda: Calanoida) from the southern California coast. Trans. Am. Micros. Soc., 96: 247-253.

Elgmork, K. and G. Halvorsen. - 1997. Intraspecific morphological variation in a freshwater copepod (Crustacea) in relation to geographic distribution and environment. Can. J. Zool., 76: 751-762.

Esterly, C.O. - 1911. Calanoida Copepoda from the Bermuda Islands. Proc. Am. Acad. Arts Sci., 47: 219-226

Fosshagen, A. - 1968. Marine Biological Investigations in the Bahamas. 4. Pseudocyclopidae (Copepoda, Calanoida) from the Bahamas. Sarsia, 32: 39-62.

Fosshagen, A. - 1970. Marine Biological Investigations in the Bahamas. 15. Ridgewayia (Copepoda, Calanoida) and two new genera of calanoids from the Bahamas. Sarsia, 44: 25-58.

Genovese, S. - 1963. Osservazioni preliminari sullo zooplancton degli stagni salmastri di Ganzirri e di Faro. Boll. Pesca, Pescic., Idrobiol., 1: 1-12.

Giesbrecht, W. - 1892. Systematik und Faunistik der pelagishen Copepoden des Golfes von Neapel und der angrenzenden Meeres-Abschnitte. Fauna und Flora Neapel XIX, pp. 507. Taf. 30, fig. 3, 18, 33; Taf. 43, fig 7, 20-22.

Huys, R. and G.A. Boxshall. - 1991. Copepod evolution. The Ray Society Editors, London, U.K.

Krišnić, F. and S.J. Malt. - 1985. Little known species of Oncaeidae (Cyclopoida) from the South Adriatic. J. Plankton Res., 7: 189-199.

Labbé, A. - 1929. Relations gènètiques de Paracartia grani G. O. Sars et d'Acartia (Acartiura) clausii Giesbrecht. Bull. Biol.
France Belgique, 63: 565-619.

Lee, C.E. and B.W. Frost. - 2002. Morphological stasis in the Eurytemora affinis species complex (Copepoda: Temoridae). Hydrobiologia, 480: 111-128.

Nishida, S. - 1985. Taxonomy and distribution of the family Oithonidae (Copepoda; Cyclopoida) in the Pacific and Indian Oceans. Bull. Ocean Res. Inst. Univ. Tokyo, 20: 1-167.

Ohtsuka, S., A. Fosshagen and S. Putchakarn. - 1999. Three new species of demersal calanoid copepod Pseudocyclops from Phuket, Thailand. Plankton Biol. Ecol., 46(Suppl.2): 132-147.

Ohtsuka, S. and R. Huys. - 2001. Sexual dimorphism in calanoid copepods: morphology and function. Hydrobiologia, 453/454: 441-466.

Sars, G.O. - 1904. Description of Paracartia grani, a peculiar Calanoid occurring in some of the Oysterbeds of Western Norway. Bergen Mus. Bergen, 4: 1-14, 3 pl

Sewell, R.B.S. - 1932. The Copepoda of the Indian Seas. Calanoida. Mem. Indian Mus., 10: 330-333.

Shmeleva, A.A. and E.P. Delalo. - 1965. A new species of the genus Oncaea (Copepoda: Cyclopoida) from the Mediterranean Sea. Zool. Zh., 44: 1562-1565 (in Russian).

Truper, H.G. and S. Genovese. - 1968. Characterization of photosynthetic sulfur bacteria causing red water in Lake Faro (Messina, Sicily). Limnol. Oceanogr., 13(Suppl. 2): 225-232.

Vervoort, W. - 1964. Free-living Copepoda from Ifaluk Atoll in the Caroline Islands with notes on related species. Bull. U.S. Natn. Mus., 236: 1-431

Wells, J.B.J. - 1967. The littoral Copepoda (Crustacea) from Inhaca Island, Mozambique. Trans. R. Soc. Edinburgh, 67: 189-358.

Zagami, G., G. Costanzo and N. Crescenti. - 2005. First record in Mediterranean Sea and redescription of the bentho-planktonic calanoid copepod species Pseudocyclops xiphophorus Wells, 1967. J. Mar. Systems, 55: 67-76.

Scient. ed.: M. Alcaraz.

Received April 8, 2008. Accepted October 8, 2008.

Published online March 4, 2009. 